\title{
The frontal eye field
}

Pierre Bourdillon, MD, Marc Guénot, MD, PhD, Pierre-Aurélien Beuriat, MD, and Karine Ostrowsky-Coste, MD

Neurology ${ }^{\circledR}$ 2018;91:e398-e399. doi:10.1212/WNL.0000000000005861
Correspondence

Dr. Bourdillon

pierre.bourdillon@

neurochirurgie.fr

Figure Anatomical location of the frontal eye field (FEF)

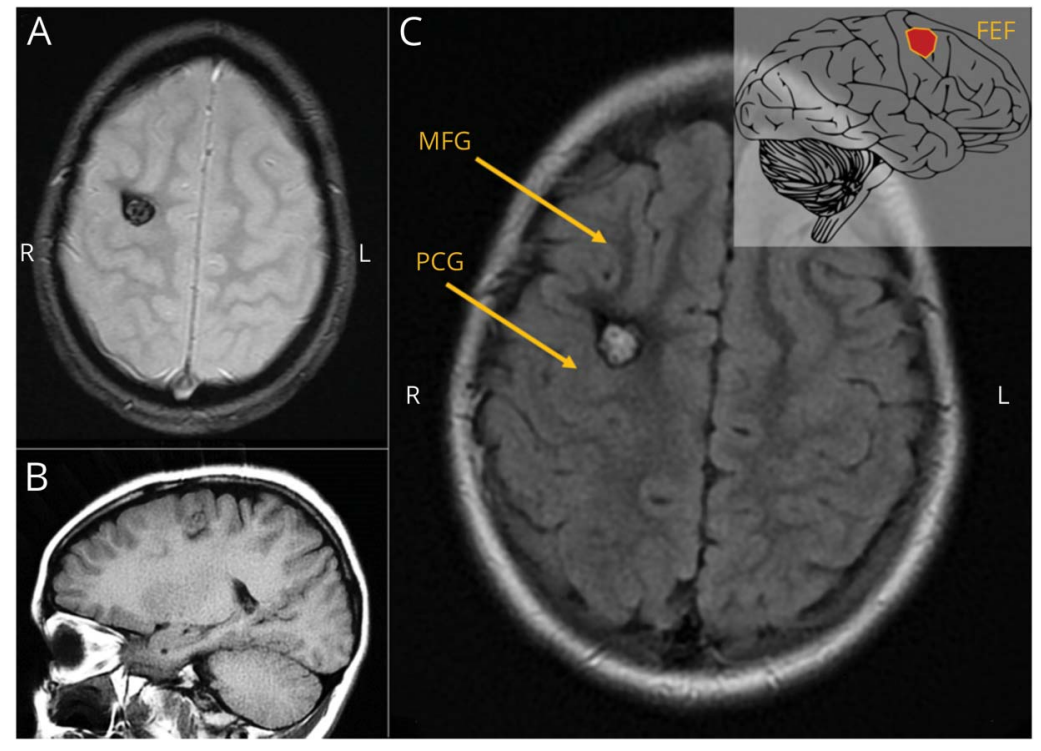

Brain MRI shows the classic "popcorn" appearance of cavernoma. (A) T2* axial slice. (B) T1 sagittal slice. (C) Fluidattenuated inversion recovery axial slice. MFG $=$ middle frontal gyrus; PCG = precentral gyrus.

An 11-year-old right-handed girl without any medical history developed epilepsy (5-10 seizures per day). During seizures, she presented a conscious tonic eye deviation to the left. EEG found a focal discharge in F4 (video) and brain MRI a cavernoma in the right frontal eye field (FEF; figure). Surgery was performed after phase 1 investigation. Pathology confirmed diagnosis; the patient is now seizure-free without neurologic impairment.

The FEF corresponds to Brodmann area 8 at the intersection of the precentral gyrus with the middle frontal gyrus (figure). ${ }^{1}$ Contralateral eye deviation is uncommonly isolated during seizures but has a high localizing value. ${ }^{2}$

\section{Author contributions}

P. Bourdillon: acquisition of data, study concept and design, study supervision, analysis and interpretation. M. Guénot: study concept and design. P.A. Beuriat: revision of the manuscript. K. Ostrowsky-Coste: acquisition of data, study concept and design, critical revision of the manuscript for important intellectual content, analysis and interpretation.
MORE ONLINE

\section{- Video}

\section{$\rightarrow$ Teaching slides}

links.lww.com/WNL/

A590

\section{Study funding}

No targeted funding reported.

From the Department of Neurosurgery (P.B., M.G.), Neurology \& Neurosurgery Hospital Pierre Wertheimer, and Departments of Pediatric Neurosurgery (P.-A.B.) and Sleep, Epilepsy and Pediatric Clinical Neurophysiology (K.O.-C.), Woman Mother Child Hospital, Hospices Civils de Lyon; Claude Bernard University (P.B., M.G., P.-A.B.), University of Lyon; Brain and Spine Institute (P.B.), INSERM U1127, CNRS 7225; and Sorbonne University (P.B.), Pierre et Marie Curie University, Paris, France.

Go to Neurology.org/N for full disclosures. Funding information and disclosures deemed relevant by the authors, if any, are provided at the end of the article. 


\section{Disclosure}

The authors report no disclosures relevant to the manuscript. Go to Neurology.org/N for full disclosures.

\section{References}

1. Godoy J, Lüders H, Dinner DS, Morris HH, Wyllie E. Versive eye movements elicited by cortical stimulation of the human brain. Neurology 1990;40:296-299.

2. Kellinghaus C, Lüders HO. Frontal lobe epilepsy. Epileptic Disord 2004;6:223-239. 


\section{Neurology}

The frontal eye field

Pierre Bourdillon, Marc Guénot, Pierre-Aurélien Beuriat, et al.

Neurology 2018;91;e398-e399

DOI 10.1212/WNL.0000000000005861

This information is current as of July 23, 2018

\section{Updated Information \&} Services

References

Subspecialty Collections

Permissions \& Licensing

Reprints including high resolution figures, can be found at: http://n.neurology.org/content/91/4/e398.full

This article cites 2 articles, 1 of which you can access for free at: http://n.neurology.org/content/91/4/e398.full\#ref-list-1

This article, along with others on similar topics, appears in the following collection(s):

\section{EEG}

http://n.neurology.org/cgi/collection/eeg_

Epilepsy semiology

http://n.neurology.org/cgi/collection/epilepsy_semiology

Information about reproducing this article in parts (figures,tables) or in its entirety can be found online at:

http://www.neurology.org/about/about_the_journal\#permissions

Information about ordering reprints can be found online:

http://n.neurology.org/subscribers/advertise

Neurology ${ }^{\circledR}$ is the official journal of the American Academy of Neurology. Published continuously since 1951, it is now a weekly with 48 issues per year. Copyright () 2018 American Academy of Neurology. All rights reserved. Print ISSN: 0028-3878. Online ISSN: 1526-632X.

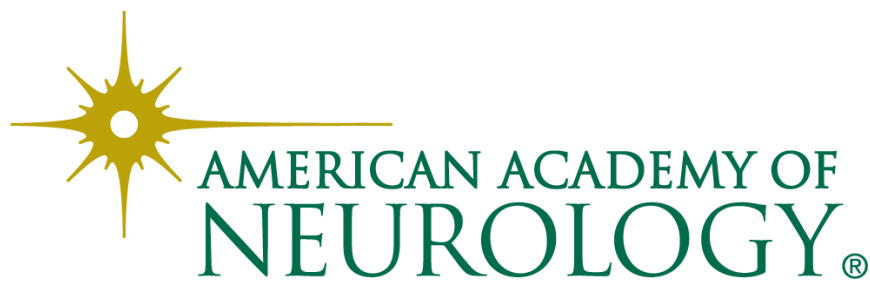

